\title{
INNOVATION OF PREDICTION EQUATIONS FOR MILK COMPOSITION ESTIMATION IN MILK RECORDING AT ALTERNATIVE SAMPLING AND HALF A DAY MILKING INTERVAL
}

\author{
O. Hanuš, P. Hering, P. Roubal, G. Chládek, A. Dufek, R. Jedelská, M. Vyletělová, \\ J. Höfer
}

Received: August 21, 2012

\begin{abstract}
HANUŠ, O., HERING, P., ROUBAL, P., CHLÁDEK, G., DUFEK, A., JEDELSKÁ, R., VYLETĚLOVÁ, M., HÖFER, J.: Innovation of prediction equations for milk composition estimation in milk recording at alternative sampling and half a day milking interval. Acta univ. agric. et silvic. Mendel. Brun., 2012, LX, No. 6, pp. 103110

At dairying cost reduction and effort about maintenance of milk recording (MR) range the MR cost decrease is also important. Aim was to revise the older prediction equations for alternative reduced milk sampling (morning - M or evening - E) for assurance of MR reliable results at twice milking a day (TMD) with balanced interval 12/12. Individual milk samples ( $\mathrm{n}=619$ animals) were obtained during TMD (M, E and REF; $\mathrm{n}=1857$ samples). Fat (F), protein (P), lactose (L) and somatic cell count (SCC) were analysed. Czech Fleckvieh and Holstein breeds were included. The reference values (REF) of day milking were obtained in regular MR (A4P). M and E milking results were related to the REF. Older prediction equations with lower validity because of time and breeding were revised: a) for $\mathrm{F}$ from $\mathrm{M}$ on REF $y=0.6932 x+1.381$, where $\mathrm{r}=0.752$ and $\mathrm{P} \leq 0.001$; b) for $\mathrm{P}$ from $\mathrm{M}$ on REF $\mathrm{y}=0.9432 \mathrm{x}+0.2274$, where $\mathrm{r}=0.949$ and $\mathrm{P} \leq 0.001$; $\mathrm{c}$ ) for $\mathrm{L}$ from $\mathrm{E}$ on $\mathrm{REF} \mathrm{y}=0.8145 \mathrm{x}+0.9095$, where $\mathrm{r}=0.87$ and $\mathrm{P} \leq 0.001$; d) for $\log$ SCC from E on REF $y=0.8829 x+0.2367$, where $r=0.94$ and $P \leq 0.001$. MR cost reduction is possible using method of alternative sampling including corresponding prediction equations.
\end{abstract}

cow, individual milk sample, fat, protein, somatic cell count

Permanent pressure on cost reduction exists in dairying including milk recording (MR) from economical reasons. Also according to ICAR materials (guidelines, International Committee for Animal Recording, 2011), the MR is still important breeder measure for genetical improvement of dairy cow populations in spite of assertion of modern molecular genetic methods as genomic scanning for advance selection of animals. Information about real own yield of an animal and yield test its offspring is still irreplaceable.

As Hering et al. (2005) cite prof. Taufer (18691940): There are no cultivating actions without a yield control and any culture breed dies without genetic transmission control. Therefore the control of parental matter husbandry and nutrient circles cannot only be a temporary improvement action but a permanent cultivating work. This fact has to be accepted not only by those managing yield and genetic transmission control but also by those in whose herds the control is carried out.

This is possible to reduce costs on sampling by selection of alternative procedure in months during lactation (morning, evening, morning, evening....) to keep possibility for maintenance of milk recording range. This method A4A (whole day milking in $\mathrm{kg}$ and reciprocal sample morning or evening and A4T alternate partial milking in $\mathrm{kg}$ of milk and relevant sample) existed always in ICAR materials for MR beside more demanding and more reliable procedure of sampling of all day milkings at milk sample creation by proportional way (A4P) at using of milking weight. 
Equations for correction of results of morning and evening milking to composition of whole day milk sample in system of MR in the Czech Republic (CR) for milking twice a day with balanced interval (12/12) are already older regarding changes caused by genetical improvement in dairy cow population during time. These can have more restricted actual validity due to mentioned facts. MR authorized by ICAR organization is very important for confession of international business with breed material. Therefore, used procedures have to be validated. Aim of this work was to carry out a revision and actualization of relevant equations in the CR MR system.

\section{MATERIAL AND METHODS}

\section{Animals and their breed, milk samples, conditions of rearing and milking}

Cow herds with twice a day milking and regular interval (12/12 hours) were included in observation. There were 2 herds of Czech Fleckvieh (CF) cattle breed in region Plzeň - south (449 dairy cows) and 1 herd with both CF and Holstein $(\mathrm{H})$ breed in region Ústí nad Orlicí (187 dairy cows). Milk recording results of last control year in herds 1, 2 and 3 were: 1) $7056 \mathrm{~kg}$ of milk per lactation (305 days), $4.05 \%$ of fat, $286 \mathrm{~kg}$ of fat, $3.65 \%$ of protein and $258 \mathrm{~kg}$ of protein; 2) 7519, 3.93, 296, 3.45 and 259; 3) $8310 \mathrm{~kg}$, $3.79 \%, 315 \mathrm{~kg}, 3.40 \%$ and $283 \mathrm{~kg}$. Milk samples (MSs) were taken stepwise according to localities in period from November 2011 to August 2012. The binding and free stabling were used in stables with pipeline and parlour milking different types from various producers. Dairy cow nutrition was typical for conditions of the Czech Republic in relevant season. Roughage feeding rations were supplemented by concentrates in accordance with feeding standards. The nutrition was characterized by total mixed ration.

Experimental individual MSs were taken by workers of Czech-Moravia Breeders Association (CMBA, organization which is responsible for MR in the CR and member of ICAR) simultaneously with regular MR. MSs were collected in this way that whole day individual milk in MR was represented by one halving sample (A4P) from both milkings (REF) and two samples of partial milking (morning (M) and evening (E)) with interval 12/12 hours ( $\mathrm{n}=1272$ MSs and 636 animals in total).

\section{Analyses of individual milk samples}

MSs were preserved using D\&F Control Systems Microtabs (bronopol, $0.03 \%$ in milk) tablets and transported under refrigerator conditions $\left(<10{ }^{\circ} \mathrm{C}\right)$ to laboratory. Samples were analysed in accredited laboratories for milk analyses Buštěhrad and Brno (ZL 1312.2, ZL 1312.3 respectively). These cooperate in routine analytical system of MR (CMBA). MSs were analysed for contents of fat (F; g.100 $\mathrm{g}^{-1}$ ), crude protein (P; g.100 $\mathrm{g}^{-1}$ ) and lactose (L; lactose monohydrate; g. $\left.100 \mathrm{~g}^{-1}\right)$ and for somatic cell count (SCC; $10^{3} \cdot \mathrm{ml}^{-1}$ ). The instruments MilkoScan FT 6000 (Foss, Denmark) and Bentley 2500 (F, P, L; filter technology of milk infrared spectroscopy; Bentley Instruments, USA) and Somacount 500 (SCC; FC, flow fluor-opto-electronic cytometry; Bentley Instruments, USA) were used for analyses.

\section{Statistical evaluation}

Results from recording of partial milkings ( $M$ and E) were related to reference (REF) result of MR, it means to whole day milk (HeRING et al., 2010; HaNuš et al., 2011 a, b; CHLÁDEK et al., 2011). Milk indicators such as F, P and L were evaluated in original values. SCCs were evaluated also in logarithmically transformed form because of lognormal frequency distribution occurrence in individual MSs. Programme Excel Microsoft was used for data calculation. Extreme values were excluded using Grubb's test $(0.05 \%)$ in milk indicator data sets (F, $\mathrm{P}, \mathrm{L}, \mathrm{SCC}$ and $\log$ SCC) in M and E groups. This was carried out in whole milking data set (REF) for milk fat as known critical factor of homogeneity and variability of sampling. Number of MSs was eliminated to $\mathrm{n}=619$ animals.

In general, REF value represented the halving sample for whole day milking. The arithmetical means, geometrical means (for SCC), standard deviations and variability coefficients were calculated in sets of components of individual milkings ( $\mathrm{M}$ and $\mathrm{E}$ ) and whole day milking (REF). Also median was expressed. The linear and nonlinear (exponential) regression were calculated between $\mathrm{M}$ and E milking values (x) and REF (y). Also determination and correlation coefficients or indexes were expressed. The selection of prediction equations for estimation of whole day milk sample composition from $\mathrm{M}$ and $\mathrm{E}$ milking was carried out. These equations with highest correlation coefficients or indexes were chosen. It means equations with highest measure of REF variability explanation by M or E milking variability.

\section{RESULTS AND DISCUSSION}

Basic statistical parameters of observed milk indicators F, P, L and SCC in model files from M, E and whole (REF) milking are shown in Tab. I. F and $\mathrm{P}$ mean values were higher in evening (4.17 > 3.90 and $3.74>3.63 \%$ ) as compared to morning samples. SKÝPALA and CHLÁDEK (2008) found significant difference for milk proteins between $\mathrm{E}$ and $\mathrm{M}$ samples (3.27 and 3.24\%). Further, they showed significantly higher fat content in evening (4.41\%) as compared to morning samples (3.95\%). It is in accordance with results of this work. Mean values and especially variability characteristics are comparable with other papers on individual MSs (Janư et al., 2007 and HANUš et al., 2007) of $\mathrm{H}$ and CF breed at corresponding milk yield in MR. Only mean protein values were clearly higher in here watched file. That is why this data file has a model 
value for determination of prediction equations. Also SCC values, especially low geometrical means (90 and $8610^{3} \cdot \mathrm{ml}^{-1} \mathrm{E}$ and M; Tab. I), showed on relatively good health state of mammary glands of observed dairy cow herds.

The linear dependencies (Tab. II) at all milk indicators were prefered for application. These showed higher prediction reliability in comparison to non linear dependencies (Fig. 1) at majority of indicators also in previous evaluations (HERING et al., 2010; Hanuš et al. 2011 a, b; CHLÁdeK et al., 2011). As a rule, it was given by higher values of determination coefficient, when linear dependence showed higher percentage of variability explanation of dependent variable value of (REF, whole day milking values) by independent variable value variability (values of $\mathrm{M}$ and $\mathrm{E}$ alternative sampling; Fig. 2 and 3 ).

Values of chosen correlation coefficients (Tab. II; at linear relationships) moved from 0.710 ( $\mathrm{P} \leq 0.001$; $\mathrm{F}$, calculation from $\mathrm{E}$ on REF) to 0.949 ( $\mathrm{P}<0.001$; $\mathrm{P}$, calculation from $\mathrm{M}$ on REF). Therefore there were close and very close relationships. There was 50.4\%

I: Basic statistical characteristics of milk recording data files, evening (E), morning (M) and reference value (REF, whole day)

\begin{tabular}{|c|c|c|c|c|c|c|}
\hline Parameter & Sample & $\mathbf{F}$ & $\mathbf{P}$ & $\mathbf{L}$ & SCC & $\log$ SCC \\
\hline $\mathrm{x}$ & & 4.17 & 3.74 & 4.83 & 270.91 & 1.9557 \\
\hline g & & & & & & 90 \\
\hline sd & & 0.745 & 0.412 & 0.290 & 751.079 & 0.605 \\
\hline $\min$ & & 1.49 & 2.74 & 2.58 & 5 & 0.6990 \\
\hline $\max$ & & 6.64 & 5.14 & 5.92 & 9509 & 3.9781 \\
\hline$n$ & M & 619 & 619 & 619 & 619 & 619 \\
\hline $\mathrm{x}$ & & 3.90 & 3.63 & 4.80 & 258.11 & 1.9344 \\
\hline vX & & 20.0 & 10.7 & 5.8 & 260.4 & \\
\hline $\mathrm{m}$ & & 3.88 & 3.61 & 4.85 & 87 & 1.9395 \\
\hline $\min$ & & 1.14 & 2.57 & 2.78 & 5 & 0.6990 \\
\hline $\max$ & & 7.49 & 4.74 & 5.88 & 7111 & 3.8519 \\
\hline$n$ & REF & 619 & 619 & 619 & 619 & 619 \\
\hline $\mathrm{x}$ & & 4.08 & 3.65 & 4.84 & 247.61 & 1.9634 \\
\hline g & & & & & & 92 \\
\hline sd & & 0.717 & 0.385 & 0.272 & 601.387 & 0.568 \\
\hline
\end{tabular}

$\mathrm{n}=$ number of cases; $\mathrm{x}$ = arithmetical mean; $\mathrm{g}=$ geometrical mean; $\mathrm{sd}=$ standard deviation; $\mathrm{vx}=$ coefficient of variation (\%); $\mathrm{m}=$ median; $\mathrm{min}=$ minimum; $\max =$ maximum; $\mathrm{F}=$ fat $\left(\mathrm{g} .100 \mathrm{~g}^{-1} ; \%\right) ; \mathrm{P}=$ crude protein $\left(\mathrm{g} .100 \mathrm{~g}^{-1} ; \%\right) ; \mathrm{L}=$ lactose monohydrate (g.100g-1; \%); SCC = somatic cell count $\left(10^{3} \cdot \mathrm{ml}^{-1}\right)$

F
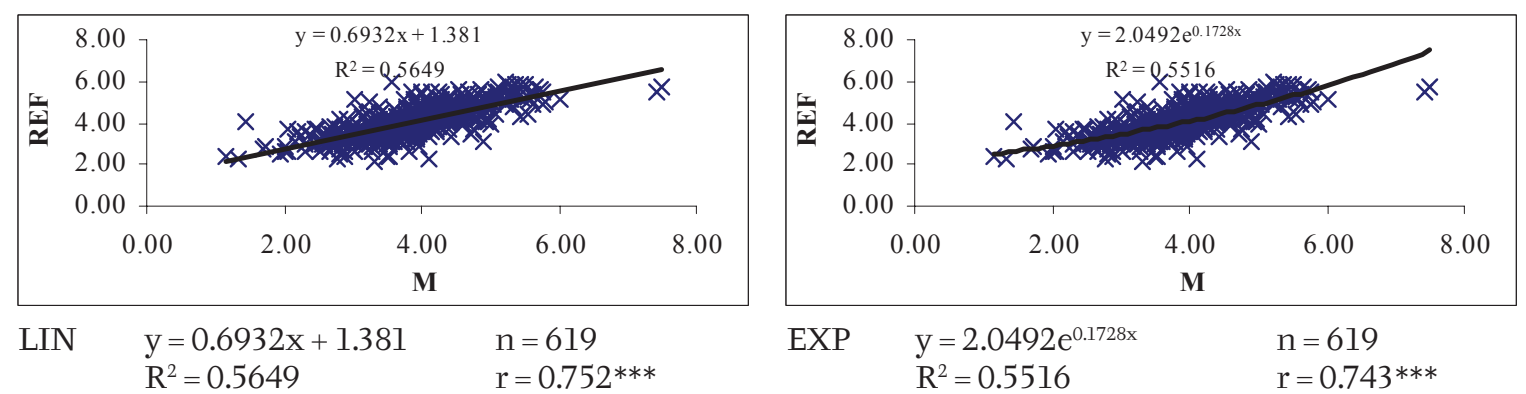

1: Linear and exponential relationship between morning $(M)$ value and REF value (whole milk recording) for fat (g.100 $g^{-1}$; \%) in individual milk samples 
II: Linear (LIN) and exponential (EXP) equations between alternative milking sample results (E or $M$ ) and whole milk recording results (REF, individual milk samples)

\begin{tabular}{|c|c|c|c|c|c|c|}
\hline Component & Sample & Relation & Equation & $\mathbf{R}^{2}$ & $\mathbf{r}$ & sig \\
\hline \multirow[t]{2}{*}{$\mathbf{F}$} & M x REF & LIN & $y=0.6932 x+1.381$ & 0.5649 & 0.752 & $* * *$ \\
\hline & & EXP & $\mathrm{y}=2.0492 \mathrm{e}^{0.1728 \mathrm{x}}$ & 0.5516 & 0.743 & $* * *$ \\
\hline \multirow[t]{2}{*}{$\mathbf{P}$} & & LIN & $y=0.9432 x+0.2274$ & 0.9004 & 0.949 & $* * *$ \\
\hline & & EXP & $\mathrm{y}=1.419 \mathrm{e}^{0.2588 \mathrm{x}}$ & 0.8947 & 0.946 & $* * *$ \\
\hline \multirow[t]{2}{*}{$\mathbf{L}$} & & LIN & $y=0.8164 x+0.9252$ & 0.6875 & 0.829 & $* * *$ \\
\hline & & EXP & $\mathrm{y}=2.0275 \mathrm{e}^{0.1811 \mathrm{x}}$ & 0.6670 & 0.817 & $* * *$ \\
\hline \multirow[t]{2}{*}{ SCC } & & LIN & $y=0.8239 x+34.958$ & 0.8481 & 0.921 & $* * *$ \\
\hline & & EXP & $y=68.109 e^{0.0012 x}$ & 0.3564 & 0.597 & $* * *$ \\
\hline \multirow[t]{2}{*}{$\log \mathrm{SCC}$} & & LIN & $y=0.8633 x+0.2935$ & 0.8465 & 0.920 & $* * *$ \\
\hline & & EXP & $y=0.7835 e^{0.452 x}$ & 0.7982 & 0.893 & $* * *$ \\
\hline \multirow[t]{2}{*}{$\mathbf{F}$} & Ex REF & LIN & $y=0.6833 x+1.2349$ & 0.5039 & 0.710 & $* * *$ \\
\hline & & EXP & $\mathrm{y}=1.9848 \mathrm{e}^{0.1692 \mathrm{x}}$ & 0.4858 & 0.697 & $* * *$ \\
\hline \multirow[t]{2}{*}{$\mathbf{P}$} & & LIN & $y=0.8847 x+0.3402$ & 0.8950 & 0.946 & $* * *$ \\
\hline & & EXP & $\mathrm{y}=1.4617 \mathrm{e}^{0.2431 \mathrm{x}}$ & 0.8919 & 0.944 & $* * *$ \\
\hline \multirow[t]{2}{*}{$\mathbf{L}$} & & LIN & $y=0.8145 x+0.9095$ & 0.7574 & 0.870 & $* * *$ \\
\hline & & EXP & $\mathrm{y}=1.9391 \mathrm{e}^{0.1888 \mathrm{x}}$ & 0.8922 & 0.945 & $* * *$ \\
\hline \multirow[t]{2}{*}{ SCC } & & LIN & $y=0.742 x+46.592$ & 0.8588 & 0.927 & $* * *$ \\
\hline & & EXP & $y=69.821 e^{0.001 x}$ & 0.3397 & 0.583 & $* * *$ \\
\hline \multirow[t]{2}{*}{$\log \mathrm{SCC}$} & & LIN & $y=0.8829 x+0.2367$ & 0.8843 & 0.940 & $* * *$ \\
\hline & & EXP & $\mathrm{y}=0.7554 \mathrm{e}^{0.4657 \mathrm{x}}$ & 0.8463 & 0.920 & $* * *$ \\
\hline
\end{tabular}

$\mathrm{R}^{2}=$ determination coefficient; $\mathrm{r}=$ correlation coefficient; sig $=$ significance, ${ }^{* * *}=\mathrm{P} \leq 0.001$

$\mathrm{P}$
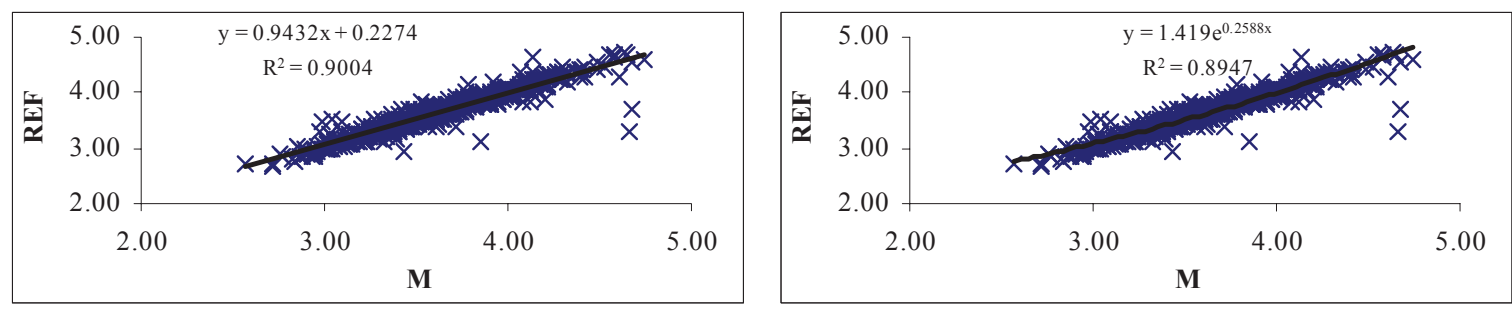

LIN $\quad \mathrm{y}=0.9432 \mathrm{x}+0.2274 \quad \mathrm{n}=619$

$$
\mathrm{R}^{2}=0.9004 \quad \mathrm{r}=0.949 * * *
$$

$\begin{array}{lll}\text { EXP } & \mathrm{y}=1.419 \mathrm{e}^{0.2588 x} & \mathrm{n}=619 \\ & \mathrm{R}^{2}=0.8947 & \mathrm{r}=0.946^{* * *}\end{array}$

2: Linear and exponential relationship between morning (M) value and REF value (whole milk recording) for crude protein (g.100 $g^{-1}$; \%) in individual milk samples

\section{$\log \mathrm{SCC}$}

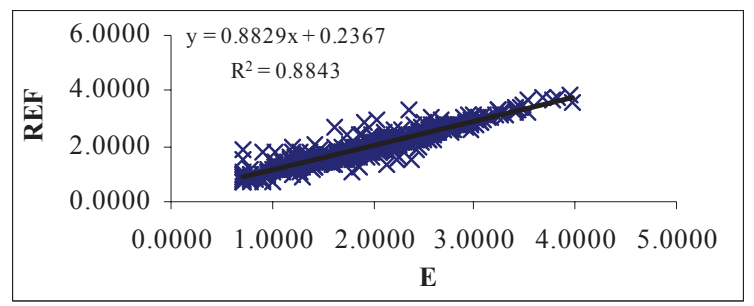

$\begin{array}{lll}\text { LIN } & \mathrm{y}=0.8829 \mathrm{x}+0.2367 & \mathrm{n}=619 \\ & \mathrm{R}^{2}=0.8843 & \mathrm{r}=0.940 * * *\end{array}$

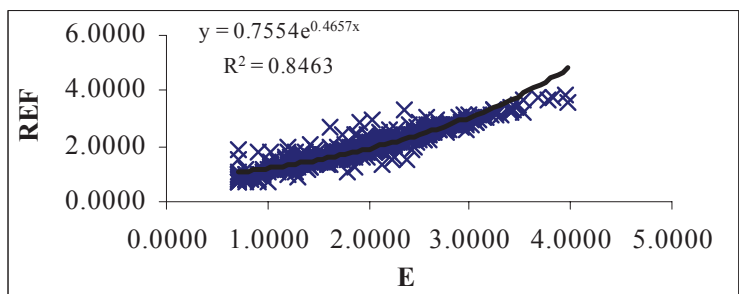

$\begin{array}{lll}\text { EXP } & \mathrm{y}=0.7554 \mathrm{e}^{0.4657 \mathrm{x}} & \mathrm{n}=619 \\ & \mathrm{R}^{2}=0.8463 & \mathrm{r}=0.920 * * *\end{array}$

3: Linear and exponential relationship between evening (E) value and REF value (whole milk recording) for log SCC (somatic cell count, $\left.10^{3} \cdot \mathrm{ml}^{-1}\right)$ in individual milk samples 
in $\mathrm{F}$ case and in $\mathrm{P}$ case as many as $90.0 \%$ of variability in REF values explainable by variability in values of partial samples which were taken by alternative variants ( $\mathrm{M}$ and $\mathrm{E}$ ). Also the REF prediction is least confident in $\mathrm{F}$ values. These results are in accordance with previous evaluation (HeRING et al., 2010). KLopčič et al., (2003) found higher prediction reliability for $\mathrm{P}$ estimation as compared to $\mathrm{F}$, which is similar finding as in this paper (Tab. II). In SCC and $\mathrm{L}$ the predicted values then have middle rate of probability. At linear estimation of REF SCC in original units (Tab. II) from alternative values ( $\mathrm{M}$ and E) was the reliability (coefficients of determination) comparable with log SCC. In theory, the estimation from log SCC values should be more advantageous but real values did not confirme it.

These results completed and extended the pieces of knowledge about estimations of resulting total values of MR from various methodical variants and modifications of individual milk sampling. Further, these results innovated the older used equations. The results contributed to line of published papers (GILBERT et al., 1972; LeE and WARDORP, 1984; Hargrove, 1994; Palmer et al., 1994; Cassandro et al., 1995; Lee et al., 1995; Jovanovac et al., 2005; Roelofs et al., 2007; GANTNER et al., 2008, 2009; JENKO et al., 2010).

Regarding relatively high tightness of dependencies (reliability) of obtained prediction equations for observed milk indicators this is possible to state hypothetically that pertinent possible differentiation of data set and its evaluation for instance according to breeds, (eventually animal blood proportions in individual cases), lactation number or stage probably would not bring any essential increase of estimation reliability. Also this evaluation came out right of real conditions of practical application.

\section{CONCLUSION}

The MR cost reduction at achievement of relatively reliable results for genetic improvement in dairy cow population is possible due to use of alternative milk sampling (morning and evening) of individual animals in MR during lactation and updated prediction equations for assesment of values of whole day milk composition in the system of twice a day milking with balanced interval (12/12 hours). The milk yield and composition results in milk recording are used, beside practical purposes, also for scientific evaluation of lactation relationships (e.g. Kopec et al., 2011; GolebiewsKi et al., 2011; ŘEHÁK et al., 2012). Recommended prediction equations are tabulated in this paper. Following choice is possible to introduce as most reliable according to milk indicators: a) for $\mathrm{F}$ from $\mathrm{M}$ on REF $\mathrm{y}=0.6932 \mathrm{x}$ +1.381 , where $\mathrm{r}=0.752$ and $\mathrm{P} \leq 0.001$; b) for $\mathrm{P}$ from $\mathrm{M}$ on REF $\mathrm{y}=0.9432 \mathrm{x}+0.2274$, where $\mathrm{r}=0.949$ and $\mathrm{P} \leq 0.001$; c) for L from $\mathrm{E}$ on REF $\mathrm{y}=0.8145 \mathrm{x}+0.9095$, where $\mathrm{r}=0.87$ and $\mathrm{P} \leq 0.001$; d) for $\log \mathrm{SCC}$ from $\mathrm{E}$ on REF $\mathrm{y}=0.8829 \mathrm{x}+0.2367$, where $\mathrm{r}=0.94$ and $\mathrm{P} \leq 0.001$. The use of equation set in possibilities of MR calculation rear can contribute to favourable ICAR audit of MR in the CR.

\section{SUMMARY}

At dairying cost reduction and effort about maintenance of milk recording (MR) range the MR cost decrease is also important. Aim of this paper was to revise the older prediction equations for alternative reduced milk sampling (morning - M or evening - E) for assurance of MR reliable results at twice milking a day (TMD) with balanced interval 12/12. Czech Fleckvieh and Holstein breed model herds were included in the estimation. MR results of last control year in herds 1, 2 and 3 were: 1) $7056 \mathrm{~kg}$ of milk per lactation (305 days), $4.05 \%$ of fat, $286 \mathrm{~kg}$ of fat, $3.65 \%$ of protein and $258 \mathrm{~kg}$ of protein; 2) 7519, 3.93, 296, 3.45 and 259; 3) $8310 \mathrm{~kg}, 3.79 \%, 315 \mathrm{~kg}, 3.40 \%$ and $283 \mathrm{~kg}$. Individual milk samples ( $\mathrm{n}=619$ animals) and their values were obtained during TMD (M, E and REF; $\mathrm{n}=1857$ samples) after removal of outliers. Fat (F), protein (P), lactose (L) and somatic cell count (SCC) were analysed (\% and $\left.10^{3} \cdot \mathrm{ml}^{-1}\right)$. The reference values (REF) of day milking were obtained in regular MR (A4P). M and E milking results were related to the REF by methods of linear and non linear regression. $\mathrm{F}$ and $\mathrm{P}$ mean values were higher in evening (4.17 > 3.90 and $3.74>3.63 \%)$ as compared to morning samples. SKÝPALA and CHLÁDEK (2008) found significant difference for milk proteins between E and M samples (3.27 and 3.24\%). Further, they showed significantly higher fat content in evening (4.41\%) as compared to morning samples (3.95\%). It is in accordance with results of this work. Values of chosen correlation coefficients (at linear relationships) moved from $0.710(\mathrm{P} \leq 0.001$; F, calculation from $\mathrm{E}$ on REF) to 0.949 ( $\mathrm{P} \leq 0.001$; $\mathrm{P}$, calculation from $\mathrm{M}$ on REF). Therefore there were close and very close relationships. There was $50.4 \%$ in $\mathrm{F}$ case and in $\mathrm{P}$ case as many as $90.0 \%$ of variability in REF values explainable by variability in values of partial samples which were taken by alternative variants ( $M$ and E). Older prediction equations with lower validity because of time and breeding were revised: a) for $F$ from $\mathrm{M}$ on REF $\mathrm{y}=0.6932 \mathrm{x}+1.381$, where $\mathrm{r}=0.752$ and $\mathrm{P} \leq 0.001$; $\mathrm{b}$ ) for $\mathrm{P}$ from $\mathrm{M}$ on $\mathrm{REF} \mathrm{y}=0.9432 \mathrm{x}$ +0.2274 , where $\mathrm{r}=0.949$ and $\mathrm{P} \leq 0.001$; $\mathrm{c}$ ) for $\mathrm{L}$ from $\mathrm{E}$ on $\mathrm{REF} \mathrm{y}=0.8145 \mathrm{x}+0.9095$, where $\mathrm{r}=0.87$ and $\mathrm{P} \leq 0.001$; d) for $\log$ SCC from $\mathrm{E}$ on REF $\mathrm{y}=0.8829 \mathrm{x}+0.2367$, where $\mathrm{r}=0.94$ and $\mathrm{P} \leq 0.001$. MR cost reduction is possible using method of alternative sampling including corresponding prediction equations. 
Acknowledgement

This contribution was prepared with support of research projects KONTAKT ME 09081, MSM 6215648905, MSM 2672286101 (RO0511 from February day 28th 2011), MSM 2678846201 (RO0311 from February day 28th 2011) and MSMT-CZ.1.07/2.3.00/09.0081 and by activities of NRL-RM. Authors also thank Mrs. M. Janecká, Mr. F. Heřman and Mr. P. Vaněk for their kind technical support and cooperation.

\section{REFERENCES}

CASSANDRO, M., CARNIER, P., GALLO, L., MANTOVANI, R., CONTIERO, B., BITTANTE, G., JANSEN, G. B., 1995: Bias and accuracy of single milking testing schemes to estimate daily and lactation milk yield. J. Dairy Sci., 78, 28842893.

GANTNER, V., JOVANOVAC, S., KLOPČIČ, M., CASSANDRO, M., RAGUŽ, N., KUTEROVAC, K., 2009: Methods for estimation of daily and lactation milk yields from alternative milk recording scheme in Holstein and Simmental cattle breeds. Ital. J. Anim. Sci., 8, 4, 519-530.

GANTNER, V., JOVANOVAC, S., RAGUŽ, N., KLOPČIČ, M., SOLIČ, D., 2008: Prediction of lactation milk yield using various milk recording methods. Biotechnology in Animal Husbandry, 24, 3-4, 9-18.

GILBERT, G. R., HARGROVE, G. L., KROGER, M., 1972: Diurnal variations in milk yield, fat yield, milk fat percentage and milk protein percentage by the test interval method. J. Dairy Sci., 56, 409410.

GOLEBIEWSKI, M., BRZOZOWSKI, P., GOLEBIEWSKI, L., 2011: Analysis of lactation curves, milk constituents somatic cell count and urea in milk of cows by the mathematical model of Wood. Acta Vet. Brno, 80, 73-80.

HANUŠ, O., FRELICH, J., JANU゚, L., MACEK, A., ZAJÍČKOVÁ, I., GENČUROVÁ, V., JEDELSKÁ, R., 2007: Impact of different milk yields of cows on milk quality in Bohemian spotted cattle. Acta Vet. Brno, 76, 4, ISSN 1801-7576, 563-571.

HANUŠ, O., HERING, P., CHLÁDEK, G., ROUBAL, P., DUFEK, A., JEDELSKÁ, R., HEŘMAN, F., 2011: Milk composition estimation according to samples which were obtained during morning and evening at triple milking a day with fixed interval in the framework of milk recording. (In Czech) Výzkum v chovu skotu / Cattle Research, LIII, 193, 1, a, 2130, ISSN 0139-7265.

HANUŠ, O., HERING, P., ROUBAL, P., LANDOVÁ, H., DUFEK, A., JEDELSKÁ, R., JANECKÁ, M., HEŘMAN, F., VANĚK, P., 201l: Validation of prediction reliability for total day milk composition from shortened sampling variants in milk recording. (In Czech) Výzkum v chovu skotu / Cattle Research, LIII, 196, 4, b, 11-24, ISSN 0139_ 7265.

HARGROVE, G. L., 1994: Bias in composite milk samples with unequal milking intervals. J. Dairy Sci., 77, 1917-1921.
HERING, P., BUCEK, P., HŘEBEN, F., PYTLOUN, P., PYTLOUN, J., MATOUŠ, E., 2005: 100 years of milk recording of cattle in Czech, Moravia and Silesia. ISBN 80-239-5481-4. 105.

HERING, P., HANUŠ, O., DUFEK, A., SAMKOVÁ, E., JEDELSKÁ, R., KRÁLÍČEK, T., KOPECKÝ, J., 2010: Estimation of milk composition in daylong sample in milk recording from partial result of morning and evening milking in the system of triplicate milking a day with variable interval. (In Czech) Výzkum v chovu skotu / Cattle Research, LII, 191, 3, 12-21.

CHLÁDEK, G., HANUŠ, O., FALTA, D., JEDELSKÁ, R., DUFEK, A., ZEJDOVÁ, P., HERING, P., 2011: Asymetric time interval between evening and morning milking and its effect on the total daily milk yield. Acta univ. agric. et silvic. Mendel. Brun., LIX, 3, 73-80, ISSN 1211-8516.

ICAR, 2010: International agreement of recording practices. Approved by the general assembly held in Riga, Latvia, on June, 479.

JANU゚, L., HANUŠ, O., FRELICH, J., MACEK, A., ZAJÍČKOVÁ, I., GENČUROVÁ, V., JEDELSKÁ, R., 2007: Influences of different milk yields of Holstein cows on milk quality indicators in the Czech Republic. Acta Vet. Brno, 76, 4, ISSN 18017576, 553-561.

JENKO, J., PERPAR, T., GORJAC, G., BABNIK, D., 2010: Evaluation of different approaches for estimation of daily yield from single milk testing scheme in cattle. J. Dairy Res., 77, 2, 137-143.

JOVANOVAC, S., GANTNER, V., KUTEROVAC, K., KLOPČIČ, M., 2005: Comparison of statistical models to estimate daily milk yield in single milking testing schemes. Ital. J. Anim. Sci., 4, Suppl. 3, 27-29.

KLOPČIČ, M., MALOVRH, Š., GORJANC, G., KOVAČ, M., OSTERC, J., 2003: Prediction of daily milk fat and protein content using alternating (AT) recording scheme. Czech J. Anim. Sci., 48, 11, 449458.

KOPEC, T., KUČERA, J., CHLÁDEK, G., VERNER, M., 2011: Using the Wood model for describing the shape of lactation curve of Czech Fleckvieh cows by lactation and year of birth. Mendel Net, 239-244.

LEE, C., POLLAK, E. J., EVERETT, R. W., MCCULLOCH, C. E., 1995: Multiplicative factors for estimation of daily milk component yields from single morning or afternoon tests. J. Dairy Sci., 78, 221-235. 
LEE, A. J., WARDORP, J., 1984: Predicting daily milk yield, fat percent, and protein percent from morning or afternoon tests. J. Dairy Sci., 67, 351360.

PALMER, R. W., JENSEN, E. L., HARDIE, A. R., 1994: Removal of within-cow differences between morning and evening milk yields. J. Dairy Sci., 77, 2663-2670.

ROELOFS, R. M. G., JONG, G., DE ROOS, A. P. W., 2007: Renewed estimation method for 24-hour fat percentage in AM/PM milk recording scheme. EAAP publication No. 121, Proceedings of the 35th Biennal Session of ICAR, Kuopio, Finland, June 2006, Breeding, production recording, health and the evaluation of farm animals, 2, 31-36, ISBN 978-90-8686-030.

К̌EHÁK, D., VOLEK, J., BARTOŇ, L., VODKOVÁ,Z., KUBEŠOVÁ,M., RAJMON,R.,2012:Relationships among milk yield, body weight, and reproduction in Holstein and Czech Fleckvieh cows. Czech J. Anim. Sci., 57, 6, 274-282.

SKÝPALA, M., CHLÁDEK, G., 2008: The chemical composition and technological properties of milk obtained from the morning and evening milking. (In Czech) Acta univ. agric. et silvic. Mendel. Brun., LVI, 5, 187-198.

Address

doc. Ing. Oto Hanuš, Ph.D., Ing. Petr Roubal, CSc., RNDr. Marcela Vyletělová, Ph.D., Mgr. Jiří Höfer, Výzkumný ústav mlékárenský, Praha, Dairy Research Institute, Prague, Ke Dvoru 12a, 16000 Praha 6 Vokovice, Česká republika, The Czech Republic, Ing. Pavel Hering, Českomoravská společnost chovatelů, a. s., Laboratoř pro rozbory mléka Buštěhrad, Czech Moravia Breeders Association (CMBA), Laboratory for milk analyses Buštěhrad, Lidická 2/334, 27343 Buštěhrad, Česká republika, The Czech Republic, prof. Ing. Gustav Chládek, CSc., Ústav chovu a šlechtění zvířat, Agronomická fakulta, Mendelova univerzita v Brně, Department of Animal Breeding, Agronomical faculty, Mendel's Univeristy in Brno, Zemědělská 1, 61300 Brno, Česká republika, The Czech Republic, Mgr. Aleš Dufek, Agrovýzkum Rapotín, AgriResearch Rapotín, Výzkumníků 267, 78813 Vikýřovice, Česká republika, The Czech Republic; Radoslava Jedelská, Výzkumný ústav pro chov skotu Rapotín, Research Institute for Cattle Breeding Rapotín, Výzkumníků 267, 78813 Vikýřovice, Česká republika, The Czech Republic, e-mail: hanus.oto@seznam.cz 
